\title{
Performance characteristics of African Cat fish (Clarias gariepinus) fed varying inclusion levels of silk worm pupae (Anaphe infracta)
}

\author{
CO Olaniyi*, GO Babasanmi
}

Department of Animal Production and Health, LadokeAkintola University of Technology, Ogbomoso, Oyo State, Nigeria

\begin{abstract}
The use of Silkworm (Anaphe infracta) pupae as a protein source was investigated for its ability to replace fishmeal in the diet of Clarias gariepinus, African cat fish. Five dried diets formulated at $40 \%$ crude protein were fed to fingerlings of an average initial weight of $14.33 \mathrm{~g}$ at 0 (control diet), 25, 50, 75 and $100 \%$ inclusion levels of silk worm meal. The experiment was conducted for 84 days were measured. Mean weight gain (MWG), specific growth rate (SGR), feed conversion ratio (FCR). The five inclusion levels of silk worm pupae supported the growth of Clarias gariepinus fingerlings, the growth and feed utilization were favoured by high inclusion level of silk worm meal. Significant differences $(p<0.05)$ were observed among the treatments, although there were no significant differences $(p>0.05)$ in the growth parameters between $50 \%$ and $75 \%$ inclusion levels. The $100 \%$ silk worm pupae meal inclusion gave the best final mean weight gain of $10.29 \mathrm{~g}$ specific growth rate of $0.93 \%$, feed conversion ratio of 2.18 and protein efficiency ratio (PER) of 0.012 . The carcass protein and lipid contents increased compared to the levels of both at the beginning of the experiment. Even though, there were no significant differences $(p>0.05)$ among proximate composition of the fish groups fed 25,50 and $75 \%$. The results showed that diet consists of $100 \%$ silk worm meal could be used as a complete replacement for fish meal in the diet formulation for Clarias gariepinus fingerlings.
\end{abstract}

Key words: Diet, growth, protein source

Bangladesh Animal Husbandry Association. All rights reserved.

Bang. J. Anim. Sci. 2013. 42 (1): 76-80

\section{Introduction}

The performance of fish meal as a feed ingredient is quite enormous. It is a feed ingredient with high nutrient digestibility. It contains high level of protein and appreciable quantity of fats and minerals. In Nigeria, and other developing countries of the world, fish meal is very scarce and expensive. Besides, availability and high cost, the quality of fish meal is quite uncertain due to the use of different part of fish and different processing technologies in its production. In addition, this often contaminated with other ingredient such as sand, saw dust and fish bones and use of chemicals for preservation often caused toxicity (Khatunet al. 2005).

Consistently, there has been recent research interest in the identification and utilization of alternative locally available feed source in feed formulation. Unconventional feed stuffs such as maggot meal (Atteh and ologbenla 1993), housefly pupae meal (El-Boushy and Van der poel 1994) Shrimp waste meal (Fanimo et al. 1996) meat meal (Rewinder et al. 1996), termite meal (Fadigimu et al. 2003) and grasshopper meal (Ojewola et al. 2005) has been used in replacing fish meal part or as whole with remarkable results. Silkworm pupae (Anaphe infracta) is sparingly consumed by some local communities. The silkworm pupae exist when the egg metamorphosed to larva and after 25-27 days, they are fully matured and then turn to the pupae, whereby they form cocoon round themselves so as to go to the next stage which is the adult. The larva feed mostly on mulberry leaves.

Mulberry is a deciduous plant with high nutritional value The proximate analysis shows that the Carbohydrate is in form of sugar which contain mainly glucose and fructose that ranged from 7.8 to $9.2 \%$, The percentage crude protein with essential amino acid ranged from 15 to $8 \%$, fatty acids like linoleic and oleic acid ranged from $4 \%$ to $0.5 \%$, malic and producing tastes $1.1-1.9 \%$, The percentage crude fibre content ranged from 0.9 to $1.4 \%$ Among the minerals present were calcium, phosphorous, and magnesium. Calcium content ranged from 1.8 to $2.4 \%$, phosphorous ranged from 1.9 to $2.87 \%$ and magnesium ranged from 0.47 to $0.63 \%$.

However, few works have been done on utilization of silkworm as feed ingredient. Habib and Hassan (1994), Solomon and Yusuf (2005) analyzed the silkworm for consumption purpose. 
Analysis shows that a silkworm pupa is rich in protein $(48.25 \%)$, Ether extract $(16.43 \%)$, as well as ash and crude fibre (12.03 and 8.42\%, respectively). This study is aimed at evaluating silkworm pupae as a dietary protein source and to determine its level of replacing fish meal in the diet of Clariasgariepinus.

\section{Materials and Methods}

\section{Experimental location}

The experiment was conducted at the fishery unit of the Ladoke Akintola University of Technology. Teaching and Research farm, Ogbomoso, Oyo State, Nigeria.

\section{Experimental diets}

A total number of five diets were formulated for the experiment. Diet 1 served as control diet. Diet $2,3,4$ and 5 contained varying level of the silkworm pupae (SWP) as 0, 25, 50, 75 and $100 \%$, respectively. The gross composition of the experimental diets was shown in Table 1.

Table 1. Gross composition of experimental diets

\begin{tabular}{llllll}
\hline Ingredients & Control & D2 & D3 & D4 & D5 \\
\hline Maize & 29.63 & 25.76 & 20.97 & 14.87 & 6.85 \\
Wheat bran & 14.82 & 12.88 & 10.49 & 7.44 & 3.43 \\
fishmeal & 54.25 & 45.04 & 33.62 & 19.09 & - \\
silkworm & - & 15.02 & 33.62 & 57.3 & 88.42 \\
veg. oil & 0.25 & 0.25 & 0.25 & 0.25 & 0.25 \\
Methionine & 0.25 & 0.25 & 0.25 & 0.25 & 0.25 \\
Lysine & 0.25 & 0.25 & 0.25 & 0.25 & 0.25 \\
Bone meal & 0.5 & 0.5 & 0.5 & 0.5 & 0.5 \\
Salt & 0.05 & 0.05 & 0.05 & 0.05 & 0.05 \\
Total \% & 100 & 100 & 100 & 100 & 100 \\
\hline
\end{tabular}

\section{Experimental procedure and fish}

A total number of 225 African cat fish fingerlings purchased from a reputable hatchery were used for the experiment. These fingerlings were raised in 50 liters circular bowls, each containing fifteen fingerlings. The fingerlings were allowed to be acclimatized for two weeks and were fed with coppens floating feeds in other to empty their guts and prepare their appetites in readiness for the administration of the experimental diet. After weeks of acclimatation, the fishes were weighed to obtain their initial weight and subsiquent weighing were carried out every two weeks. The fishes were fed $3 \%$ of their body weight.

\section{Data collection}

The parameters of interest were: mean weight gain (MWG), percentage mean weight gain (\% MWG), total feed intake( TFI), average feed intake $(A F) I$, feed conversion ratio(FCR), gross feed conversion efficiency( GFCE), specific growth rate(SGR), protein efficiency ratio (PER).

\section{Mean weight gain}

This was calculated by finding the difference between the initial mean weight and final mean weight of the experimental fish, i.e., mean weight gain $=$ final mean weight - initial mean weight.

\section{Percent mean weight gain}

This was calculated from the relationship between the mean weight gain of the fish expressed as a percentage of the initial mean weight, i.e., percent mean weight gain = MWGx100/IMW. Where, MWG = mean weight gain $(\mathrm{g})$ and IMW = initial mean weight $(\mathrm{g})$.

\section{Total feed intake}

This was obtained by getting the $3 \%$ of their body weight and multiplied by the weight of the feed fed per day. i.e., Total feed intake (TFI) $=3 \%$ body weight $x$ feed fed.

\section{Average feed intake}

This was calculated by the relationship between the total feed intake and the number of fishes and number of weeks, i.e., Average feed intake $=\mathrm{TFI}$ /No. of fishes/No. of weeks

\section{Feed conversion ratio}

This was expressed as the relationship between the average feed intake by each treatment and the mean weight gain, i.e., FCR = AFI/MWG. Where, $\mathrm{AFI}=$ Average feed intake, $\mathrm{MWG}=$ Mean weight gain

\section{Gross feed conversion efficiency (\%)}

This was expressed as the reciprocal of the feed conversion ratio, expressed as a percentage, i.e., GFCE $=1$ /feed conversion $\times 100$.

\section{Growth rate specific}

$\operatorname{SGR}(\%)=\log _{\mathrm{e}} \mathrm{W}_{2}-\log _{\mathrm{e}} \mathrm{W}_{1} / \mathrm{T}_{1} \times 100$ Where $W_{2}=$ final weight of fish, $W_{1}=$ initial weight of fish, $T_{1}-t_{1}=$ Experimental period of days, Log $_{e}$ $=$ Natural logarithm to base 2

\section{Protein intake ( $\mathrm{PI})$}


This was calculated by multiplying the feed intake by the percentage crude protein in the diet, i.e., $\mathrm{PI}=\mathrm{FI} \times \% \mathrm{CP}$. Where, $\mathrm{PI}=$ protein intake, $\mathrm{FI}=$ feed intake, $\% C P=$ percentage crude protein in the diet.

\section{Protein efficiency ratio (PER)}

This was calculated from the relationship between weight gain protein and protein intake, i.e., PER = MWG/ PI. Where, PER = protein efficiency ratio, $M W G=$ mean weight gain, $\mathrm{PI}=$ protein intake.

\section{Statistical analysis}

The data collected was subjected to analysis of variance (ANOVA) using completely randomized design of SPSS statistical package computer software (2003 version), Duncan multiple range test of the same package was used to compare the differences among individual means.

\section{Results}

The proximate composition of silkworm pupae is shown in Table 2. The crude protein of the Anaphe infracta was $51 \%$. The crude fat content was $4.73 \%$ and the ash contents, crude fibre and dry matter were found as $11.76,3.67,91.79 \%$, respectively.

Table 2. Proximate composition of anaphe infracta meal

\begin{tabular}{lc}
\hline Components & Amound in \% \\
\hline Crude protein (CP) & 51.28 \\
Ether extracts (EE) & 4.73 \\
Ash contents & 11.76 \\
Crude fibre (CF) & 3.67 \\
Dry matter (DM) & 91.79 \\
\hline
\end{tabular}

The growth performance of Clarias gariepinus fingerlings fed silkworm pupae is presented in Table 3. The mean weight gain (MWG), percentage mean weight gain ( $\% M W G)$, mean weight gain per day(MWG/day), specific growth rate (SGR), total feed intake (TFI), average feed intake (AFI), feed conversion ratio (FCR) and gross feed conversion efficiency (GFCE), were significantly different $(p<0.05)$ and there were linear relationship between the growth parameters listed below and the levels of inclusion of silkworm pupae, which means as the level of inclusion of silkworm increases in the diet, all the growth parameters listed above also increased.

Table 3. Growth performance and nutrient utilization of clariasgariepinus fingerlings fed varying levels of anapheinfracta pupae

\begin{tabular}{llllll}
\hline Parameter & $\begin{array}{l}0 \% \\
\left(\mathrm{~T}_{1}\right)\end{array}$ & $\begin{array}{l}25 \% \\
\left(\mathrm{~T}_{2}\right)\end{array}$ & $\begin{array}{l}50 \% \\
\left(\mathrm{~T}_{3}\right)\end{array}$ & $\begin{array}{l}75 \% \\
\left(\mathrm{~T}_{4}\right)\end{array}$ & $\begin{array}{l}100 \% \\
\left(\mathrm{~T}_{5}\right)\end{array}$ \\
\hline Initial MW & 14.33 & 14.33 & 14.33 & 14.33 & 14.33 \\
Final MW & $20.31^{\mathrm{b}}$ & $17.2^{\mathrm{c}}$ & $19 \mathrm{9}^{\mathrm{bc}}$ & $18.3^{\mathrm{bc}}$ & $24.62^{\mathrm{a}}$ \\
MWG & $5.98^{\mathrm{b}}$ & $2.87^{\mathrm{c}}$ & $4.67^{\mathrm{bc}}$ & $3.97^{\mathrm{bc}}$ & $10.29^{\mathrm{a}}$ \\
$\%$ MWG & $41.73^{\mathrm{b}}$ & $20.03^{\mathrm{c}}$ & $32.59^{\mathrm{bc}}$ & $27.71^{\mathrm{bc}}$ & $71.77^{\mathrm{a}}$ \\
MWG/day & $106.79^{\mathrm{b}}$ & $51.25^{\mathrm{c}}$ & $83.39^{\mathrm{bc}}$ & $70.89^{\mathrm{bc}}$ & $183.66^{\mathrm{a}}$ \\
SGR \% & $0.61^{\mathrm{b}}$ & $0.33^{\mathrm{c}}$ & $0.51^{\mathrm{bc}}$ & $0.44^{\mathrm{bc}}$ & $0.93^{\mathrm{a}}$ \\
TFI & $11844^{\mathrm{c}}$ & $13003^{\mathrm{b}}$ & $14364^{\mathrm{a}}$ & $13835^{\mathrm{a}}$ & $14137^{\mathrm{a}}$ \\
AFI & $14.1^{\mathrm{c}}$ & $15.48^{\mathrm{b}}$ & $17.1^{\mathrm{a}}$ & $16.47^{\mathrm{a}}$ & $16.83^{\mathrm{a}}$ \\
FCR & $3.26^{\mathrm{bc}}$ & $5.48^{\mathrm{a}}$ & $3.66^{\mathrm{b}}$ & $4.36^{\mathrm{b}}$ & $2.18^{\mathrm{c}}$ \\
GFCE & $45.27^{\mathrm{bc}}$ & $18.5^{\mathrm{c}}$ & $27.33^{\mathrm{bc}}$ & $23.86^{\mathrm{c}}$ & $62.73^{\mathrm{a}}$ \\
PER & $0.0083^{\mathrm{a}}$ & $0.0036^{\mathrm{d}}$ & $0.0053^{\mathrm{c}}$ & $0.0047^{\mathrm{b}}$ & $0.012^{\mathrm{a}}$ \\
\hline
\end{tabular}

Means in the same row with different subscripts are significantly different $(p<0.05)$; MWG, mean weight gain; FCR, feed conversion ratio; AFI, average feed intake; TFI, total feed intake; GFCE, Gross feed conversion efficiency; SGR, Specific growth rate

Highest values of MWG, \%MWG, SGR, and MWG/day were recorded for treatment 5 (10.29g, $71.77 \%, 0.93 \%$ and $183.66 \mathrm{~g}$, respectively), which is $100 \%$ inclusion of silkworm pupae. While the lowest values was recorded for MWG, \%MWG, GFCE, SGR and MWG/day in treatment $2(2.87 \mathrm{~g}$, $20.03 \%$, $18.50 \mathrm{~g}, 0.33 \%$, and $51.25 \mathrm{~g}$ ), respectively which is $25 \%$ inclusion of silkworm pupae.

However, least value was recorded for FCR in treatment 5 (100\% inclusion of silkworm pupae) which was 2.18. Then these shows the highest performance of the fish fed 100per cent and 50\% inclusion of silkworm pupae had the highest average feed intake $\mathrm{AFI}$, of values $16.83 \mathrm{~g}$ and $17.1 \mathrm{~g}$ respectively. This is attributed to high fibre content of silkworm pupae meal. While the least value was obtained in the control group $(14.10 \mathrm{~g})$.

The results of the proximate composition of experimental diet are presented in Table 4. The crude protein value for treatment 3 was recorded $43.06 \%$, which shows highest value among the five treatments. While the lowest value was recorded in treatment 1 as $41.36 \%$. Treatment 5 shows the highest value $(4.73 \%)$ of crude fats, and treatment 2 shows the lowest value $4.29 \%$. Furthermore, the crude fibre was highest in treatment $5(3.64 \%)$ but in treatment 3 it was lowest (3.41\%).

The proximate composition of fish carcass before and after the experiment was presented in table 5. The crude protein content of the fish at the end 
of feeding trials, fish samples fed $100 \%$ silkworm pupae meal replacement (treatment 5), had the highest crude protein content $(64.12 \%)$ while the lowest value was recorded in treatment 1 $(61.89 \%)$. The crude fibre shows no value in all the treatments. The ether extract in treatment 4 $(6.97 \%)$ shows the highest value. While the least value was recorded in treatment 3 . The highest value for ash content was recorded in treatment 5 $(11.33 \%)$ while the least value was recorded in treatment 2.

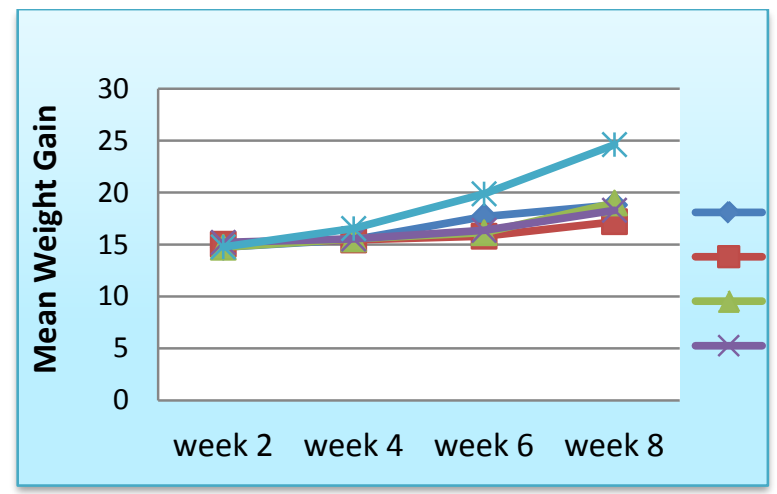

Figure 1. Relationship between the mean weight gain and age

Table 4. Proximate composition of experimental diet

\begin{tabular}{llllll}
\hline $\begin{array}{l}\text { Components } \\
(\%)\end{array}$ & $\mathrm{T}_{1}$ & $\mathrm{~T}_{2}$ & $\mathrm{~T}_{3}$ & $\mathrm{~T}_{4}$ & $\mathrm{~T}_{5}$ \\
\hline $\mathrm{DM}$ & 91.67 & 92.03 & 91.56 & 91.74 & 92.09 \\
$\mathrm{CP}$ & 41.36 & 42.54 & 43.06 & 42.97 & 42.27 \\
$\mathrm{EE}$ & 4.37 & 4.29 & 4.57 & 4.68 & 4.49 \\
$\mathrm{CF}$ & 3.46 & 3.54 & 3.41 & 3.59 & 3.64 \\
Ash & 13.88 & 14.14 & 13.79 & 14.06 & 14.11 \\
NFE & 28.6 & 27.52 & 26.73 & 26.44 & 27.58 \\
\hline
\end{tabular}

$T_{1}, T_{2}, T_{3}, T_{4}$, and $T_{5}$ contained $0,25,5075$ and $100 \%$ silkworm pupae, respectively

Table 5. Proximate carcass compositions of catfish before and after feeding trials

\begin{tabular}{llllll}
\hline $\begin{array}{l}\text { Component } \\
\text { (\%) }\end{array}$ & $\mathrm{T}_{1}$ & $\mathrm{~T}_{2}$ & $\mathrm{~T}_{3}$ & $\mathrm{~T}_{4}$ & $\mathrm{~T}_{5}$ \\
\hline $\mathrm{DM}$ & 93.42 & 93.56 & 93.61 & 93.59 & 93.66 \\
$\mathrm{CP}$ & 61.89 & 62.29 & 62.95 & 63.78 & 64.12 \\
$\mathrm{EE}$ & 6.78 & 6.85 & 6.03 & 6.97 & 6.09 \\
$\mathrm{CF}$ & 0 & 0 & 0 & 0 & 0 \\
$\mathrm{Ash}$ & 11.26 & 10.87 & 11.09 & 10.98 & 11.33 \\
$\mathrm{NFE}$ & 13.49 & 13.55 & 13.54 & 11.59 & 12.12 \\
\hline $\mathrm{T}_{1}, \mathrm{~T}_{2}, \mathrm{~T}_{3}, \mathrm{~T}_{4}$, and $\mathrm{T}_{5}$ contained 0, & 25,50 & 75 and \\
100\% silkworm pupae, respectively & &
\end{tabular}




\section{Performance of African Cat fish}

which was the highest in treatment 5 and least value of $0.3 \%$ in treatment 2 . The ether extract in treatment $4(6.97 \%)$ shows the highest value. While the least value was recorded in treatment 3 . The highest value for ash content was recorded in treatment $5(11.33 \%)$ while the least value was recorded in treatment 2 .

\section{Conclusion}

Hundred percent silkworm pupae performed best in terms of MWG, GFCE, and SGR. It can be concluded that fish meal can be replaced with silkworm pupae meal up to $100 \%$ in the diet of Clarias gariepinus fingerlings. These results of this study revealed that silkworm pupae can completely replace the scarce and expensive fish meal in Clarias gariepinus fingerlings diet without compromising performance and economic returns.

\section{Recommendation}

It is advisable for a fish farmer to replace fish meal with silkworm pupae meal up to $100 \%$ while compounding diets for Clarias gariepinus fingerlings. These will enhance the optimum growth of catfish and profit maximization for the fish farmers.

\section{References}

Atteh JO, Ologbenla FD (1993). Replacement of fish meal with maggot in broiler diet: effect on performance and nutrient retention. Nigerian Journal of Animal Production, 20: 44-49.

Duncan DB (1955). Multiple ranges and Multiple F. tests Biometrics. Wiley publisher, New York, 11: 1- 42.

El Boushy ARY, Van der poel AFB (1994). Poultry feed from waste. $1^{\text {st }}$ Edn. Chapman and Hall, London, P. 408.

Fadiyimu AA, Ayodele AO, Olowu PO, Folorunsho OR (2003). Performance of finishing broilers fed graded level of termite meals as a replacement of fish meal. The $28^{\text {th }}$ Annual Conference of Nigerian Society of Animal Production, 28: 211-212.

Fanimo AO, Moduna T, Umukoro O, Oduguwa 00 (1996). Substitution of shrimp waste meal for fish meal in broiler chicken rations. Tropical Agriculture (Trinidad), 73: 201205.

Khatun R, Azmal SA, Sarker MSK, Rashid MA, Hussain MA, Miah MY (2005). Effect of silkworm pupae on the growth and egg production performance of Rhode Island Red (RIR) pure line. International Journal of Poultry Science, 4: 718-720.

Khatun $R$, Howlinder MAR, Rahman MM, Hasanuzzaman M (2003). Replacement offish meal by silkworm pupae in broiler diets. Pakistan Journal of Biological Science, 6: 955-958.

Oduguwa OO, Fanimo AO, Oso MJ (2005). Effect of replacing dietary fish meal or soyabean with shrimp waste meal on the performance of a laying hen. Nigerian J ournal of Animal Production, 32: 244-232.

Ojewola GS, Okoye FC, Ukoha OA (2005). Comparative utilization of three animal protein sources by broiler chickens. International Journal of Poultry Science, 4: 462-467.

Ravinder VR, Qudratullah S (1996). Squilla-a novel animal protein. Can it be used as a complete substitution for fish meal in poultry ration? Feed International, 18- 20.

Robinson EH, Merghe NL, Manning BB (2001). A practical guide to Nutrition, Feeds and Feeding of Cat fish, $2^{\text {nd }}$ revision, Bulletin 1113.

Solomon SG, Yusuf II (2005). The amino acid profile, proximate and mineral composition of silkworm caterpillar (Anapheinfracta) meal as possible alternative to fish meal in the diets of cultural fish species. Department of fisheries and Aquaculture. University of Agriculture, Makurdi, Nigeria. 